\title{
Perilaku caring perawat terhadap kepuasan pasien; Sebuah literatur Review
}

\author{
Nurul Octaviani ${ }^{*}{ }^{*}$, M Zaidan Jauhari ${ }^{2}$, Rizki Yeni Wulandari ${ }^{3}$, Surmiasih $^{4}$ \\ 1,2,3, Universitas Aisyah Pringsewu
}

Email: nuruloctaviani1098@gmail.com

\begin{tabular}{l} 
ARTICLE INFO \\
\hline Keyword: \\
Caring \\
Satisfaction \\
Patient \\
Perawat \\
Nurse \\
Pasien \\
\\
*) corresponding author \\
Nurul Octaviani \\
Mahasiswa Program Studi Profesi Ners \\
Fakultas Kesehatan Universitas Aisyah \\
Pringsewu \\
Jl. A. Yani No. 1A Tambahrejo Kecamatan \\
Gadingrejo Kabupaten Pringsewu Lampung \\
35372 Telp: (0729) 333343
\end{tabular}

\begin{abstract}
Professional nurse service may be performed by a nurse in the performance of their duty. Caring will enable harmonious interpersonal relationships between nurses and patients,it can help and fulfill the patient's need to provide satisfaction. The research objective is to examine the results of several journals about nursing caring behavior to the patient's satisfaction. The research design used descriptive methods from the journal review literature. The results showed that nurses who have a good caring attitude, so patient satisfaction can be good in accordance with the quality of caring behavior performed by nurses. Based on the literature review noted that the application of nurse caring behavior has a close correlation with patient satisfaction. The more caring a nurse is, the more satisfied a patient will receive nursing care service.
\end{abstract}

\section{PENDAHULUAN}

Pelayanan kesehatan memiliki peran yang sangat strategis dalam upaya mempercepat peningkatan derajat kesehatan masyarakat.Pelayanan kesehatan harus memberikan pelayanan berkualitas sesuai kebutuhan dan keinginan pasien. Dalam perkembangan teknologi yang pesat dan persaingan yang semakin ketat, pelayanan kesehatan dituntut untuk terus melakukan peningkatan kualitas pelayanannya( Wijaya,2015). Saat ini sudah banyak orang yang menggunakan jasa perawat pelayanan kesehatan diantaranya adalah pelayanan puskesmas yang menjadi salah satu fasilitas kesehatan, karena pelayanan perawat merupakan pelayanan kesehatan yang setiap saat sangat dibutuhkan oleh pasien (Rumagit et al. 2017). Pelayanan kesehatan di Indonesia juga ikut berkembang dan mengalami perubahan yang cepat baik di bidang barang ataupun jasa pada era 
globalisasi ini. Hal tersebut tentu berdampak dan berpengaruh penting dalam bidang kesehatan. Kunci utama dalam keberhasilan pencapaian tujuan pembangunan kesehatan adalah petugas kesehatan terutama perawat dan pasien yang merasa puas dan senang mendapatkan pelayanan (Purwoastuti,2015).

Keberhasilan pelayanan kesehatan dipengaruhi oleh berbagai faktor, salah satu faktor tersebut adalah pelayanan keperawatan yang merupakan bagian yang tidak dapat dipisahkan dari pelayanan kesehatan secara keseluruhan. Pelayanan keperawatan mempunyai posisi yang sangat strategis dalam menentukan mutu pelayanan karena pemberi pelayanan professional yang terbanyak adalah perawat dan yang paling lama kontak dengan pasien selama 24 jam (Fitriyani,2017).

Riset dari beberapa Pelayanan kesehatan di Indonesia Khususnya puskesmas menyatakan bahwa rata-rata perilaku caring masih kurang, seperti di puskesmas Daerah Klaten didapatkan persentase perilaku caring di Puskesmas tersebut sebanyak (62\%), persentase ini menunjukkan bahwa caring di Puskesmas berada pada kategori rendah (Sunardi,2015).

Perilaku caring perawat sangat penting dalam memenuhi kepuasan pasien, hal ini menjadi salah satu indikator kualitas pelayanan di puskesmas. Perawat menjadi salah satu penentu dalam memenuhi kepuasan pasien ( Wibowo, 2015). Berdasarkan pada pemikiran tersebut maka dengan caring akan memungkinkan terjalinnya hubungan yang harmonis antara perawat dengan pasien dan dapat membantu sertamemenuhi kebutuhan pasien sehingga dapat memberikan kepuasan pada pasien itu sendiri ( Rahayu,2015).Dalam mengatasi masalah yang ada adalah perlu peningkatan pemahaman perawat terhadap pentingnya perilaku caring, memotivasi perawat untuk lebih meningkatkan kualitas caring dalam memberikan asuhan keperawatan serta melakukan monitoring terhadap perilaku caring perawat dalam melaksanakan asuhan keperawatan dan mengedepankan prinsip-prinsip caring. Semakin baik perilaku caring perawat dalam memberikan pelayanan keperawatan kepada pasien maka tingkat kepuasan pasien terhadap pelayanan keperawatan akan semakin baik juga (Watson, 2017).

\section{METODE}

Literature review ini menggunakan critical review artikel full text lima tahun terakhir yaitu dari tahun 2015-2020 dalam bahasa indonesia dan bahasa inggris yang memenuhi kriteria PICO dan SPIDER. Karena keterbatasan artikel maka digunakan studi kuantitatif untuk mendapatkan hasil review yang lebih akurat. Pencarian data base Google Scholar, Perpustakaan Nasional Republik Indonesia, PubMed, Proquest dengan kata kunci "caring” "Satisfaction “, "Nursing Caring Behavior to the Patients Satisfaction". Untuk mendapatkan artikel yang sesuai dengan topik dan tujuan. Didapatkan 187 artikel di PubMed, 44 artikel di Proquest, 550 artikel di Google Scholar, 15 artikel di Perpustakaan Nasional Republik Indonesia. Selanjutnya dilakukan Pembacaan artikel secara intensif dan dibuatkan ringkasan dari setiap artikel.

\section{HASIL DAN PEMBAHASAN}

Perilaku caring merupakan manifestasi perhatian kepada orang lain, berpusat pada orang, menghormati harga diri dan kemanusiaan. Caring mempunyai komitmen untuk mencegah terjadinya sesuatu yang buruk, memberi perhatian dan menghormati orang lain di kehidupan manusia. Caring juga merupakan ungkapan cinta dan ikatan, otoritas dan keberadaan, selalu bersama, empati, dapat memotivasi perawat untuk dapat lebih care pada klien mampu melakukan tindakan sesuai kebutuhan klien ( Dwidiyanti,2015). Hal ini perawat yang memberikan caring terhadap klien yang berarti perawat sudah dapat menunjukkan perhatian, tanggung jawab atas perawatan yang diberikan terhadap klien, dan juga merawat klien dilakukan dengan tulus dan ikhlas (Lestari,2015). 
Menurut teori Watson dalam Kusmiran (2015), dalam praktik keperawatan ada struktur ilmu caring yang dibangun berdasarkan 10 faktor karatif yang harus dimiliki perawat dan ditetapkan dalam memberikan asuhan keperawatan pada pasien.Hasil penelitian (Fitri, 2018) didapatkan perilaku caring yang sudah baik terdapat pada karatif nilai humanistic dan altruistic mengatakan perawat memberikan perhatian kepada pasien selama merawat pasien. Dari studi penelitian Arsi (2018), Damayanti (2015), Hedri(2016) menunjukkan bahwa semakin baik perilaku caring perawat dalam memberikan asuhan keperawatan, pasien dan keluarga semakin senang dalam menerima pelayanan. Hal ini sejalan dengan dengan tinjauan pustaka menurut teori caring yang dikemukakan oleh Watson (1979). Pembentukan sistem nilai humanistic-altruistik dibangun dari pengalaman hidup, belajar dan juga dapat ditingkatkan selama masa pendidikan perawat dan berasal dari diri sendiri. Sifat perawat yang mencerminkan nilai humanistik-Altruistik ialah perawat memberikan kebaikan dan kasih sayang serta membuka diri untuk melakukan tindakan terapi dengan klien (Desima,2015). Perawat memberikan keyakinan dan kepercayaan dengan cara memfasilitasi dan meningkatkan asuhan keperawatan yang holistic. Dalam hubungan perawat dan klien yang efektif, perawat memfasilitasi perasaan optimis, harapan dan kepercayaan. Di samping itu, perawat meningkatkan perilaku klien dalam mencari pertolongan kesehatan untuk menciptakan suasana lebih baik melalui kepercayaan yang sangat berarti bagi seseorang individu (Suliano,2016). Perilaku caring perawat dapat dilihat penerima ungkapan positif dan negative dari klien. Hal tersebut sejalan dengan penelitian (Juwariyah,2014) bahwa perawat sudah dapat memahami dengan ungkapan positif dan emosional pada keadaan yang dialami oleh klien. Dengan adanya perilaku caring yang baik, maka klien mengungkapkan perasaannya tentang perawat sebagai pemberi pelayanan asuhan keperawatan akan baik sehingga kepuasan akan pelayanan asuhan keperawatan juga akan baik. Kepuasan pasien tergantung pada kinerja dalam memberikan suatu pelayanan, bila kinerja jauh lebih rendah daripada harapan pasien, pasien tidak puas dan bila kinerja pelayanan sesuai dengan harapan maka pasien merasa sangan puas atau dapat diartikan sebagai perbandingan antara harapan yang dimiliki pasien dengan kenyataan yang diterima oleh pasien pada saat menerima pelayanan (Kotler,2015).

Dalam literature review pada 6 artikel ini yang membahas tentang perilaku caring perawat terhadap kepuasan pasien didapatkan hasil bahwa pada perawat yang mempunyai sikap caring yang baik maka kepuasan pasien bisa terpenuhi sesuai harapan pasien dan sesuai dengan kualitas perilaku caring yang diberikan oleh perawat. Melihat besarnya manfaat caring tercermin dalam setiap interaksi antara perawat dan pasien karena bersikap caring terhadap pasien merupakan indikator utama dalam pelayanan keperawatan.Bentuk hubungan antara perawat dan pasien juga adalah hubungan yang harus dipertanggung jawabkan secara professional. Maka dari itu dengan Pelaksanaan caring yang sebaik-baiknya akan meningkatkan mutu pelayanan keperawatan, memperbaiki image perawat di masyarakat dan membuat profesi keperawatan menjadi baik di mata para pengguna jasa pelayanan kesehatan.

\section{KESIMPULAN DAN SARAN}

Dari studi Literature Review yang sudah dilakukan oleh peneliti didapatkan hasil bahwa seorang perawat memiliki hubungan yang erat kaitannya dengan kepuasan pasien. Semakin caring seorang perawat dalam memenuhi harapan yang diinginkan oleh pasien maka akan semakin puas seorang pasien yang mendapatkan pelayanan keperawatan. Perilaku caring perawat sangat penting dalam memenuhi kepuasan pasien karena menjadi salah satu indikator utama dalam kualitas pelayanan rumah sakit dan Menumbuhkan rasa cinta dan memiliki terhadap profesi keperawatan dengan cara menerapkan perilaku caring dalam asuhan keperawatan yang tidak hanya didasari faktor financial, tetapi tumbuh dari kesadaran moral dari perawat untuk menolong sesama manusia. 


\section{DAFTAR PUSTAKA}

Abdul,Asri. 2017. Hubungan Antara Caring Perawat Dengan Tingkat Kepuasan Pasien. Jurnal kesehatan, 3(1), 30-36.

Akbar, Patria. 2015. Gambaran Kepuasan Pasien Terhadap Pelaksanaan Komunikasi Teraupetik Perawat Di Instalasi Rawat Inap RSUD Labuang Makassar. Jurnal psikologi Vol.1 No.2.

Azizah.,Nur. 2018. Hubungan Sikap Caring Perawat Dengan Terpenuhinya Hak Pasien Mendapatkan Informasi Tindakan di Rawat Inap RSU PKU Muhammadiyah Bantul Yogyakarta. E.Journal Vol.2 No.3.

Damayanti.2016. Analisis Faktor yang Berhubungan Dengan Kepuasan Pasien Rawat Inap di Rumah Sakit Islam Surakarta.Universitas Muhammadiyah Surakarta. Konselor, 5(2), 93-99.

Dedi,B. Setyowati Afiyanti. 2018. Perilaku Caring Perawat Pelaksana Studi Grounded Theory. Jurnal Keperawatan Indonesia: Vol 1 No 4.

Hans. 2017. Hubungan Antara Persepsi Pasien Terhadap Dimensi Mutu Pelayanan Keperawatan dengan Kepuasan Pasien.Jurnal Keperawatan Vol 1 No.2 : 33-37.

Kalsum. 2016. Hubungan Perilaku Caring Perawat dengan Kepuasan Pasien di Ruang Perawatan Teratai Rumah Sakit Umum Pusat Fatmawati. Journal Vol.2 No.1.

Lestari,P. Sunarto dan Kuntari,T. 2017. Analisa Penentu Tingkat Kepuasan Pasien di Rumah Sakit PKU Muhammadiyah Bantul. Jurnal Keperawatan Vol.23 No.2.

Prihandhani,S. 2015. Hubungan Faktor Individu dan Budaya Organisasi dengan Perilaku Caring Perawat Pelaksana di Ruang Rawat Inap RSU Ganesha Gianyar.E-Journal Keperawatan Vol 3 No 2.

Purwoastuti. 2015. Sikap Caring Perawat dalam Memberikan Asuhan Keperawatan Pada Pasien di Ruang ICU RSUD dr.Soediran Mangun Sumarso Wonogiri. Skripsi. Program Studi Keperawatan STIKes Kusuma Husada Surakarta

Rumagit, et al. 2017.Hubungan Perilaku Caring Perawat dengan Tingkat Kepuasan Pasien Rawat Inap Rumah Sakit Makassar: Program Studi Ilmu Keperawatan Universitas Hasanuddin

Sitorus,d. 2015. Analisis Faktor yang Mempengaruhi Kinerja Mutu Pelayanan di RSUD dr.M.Haulussy Ambon Makassar : Universitas Hasanuddin

Sandra, Rhona. 2016. Hubungan Komunikasi Terapeutik perawat Dengan Kepuasan Pasien Di Ruang Instalasi Rawat Inap RSUP Dr.DJamil. Universitas Indonesia: Depok

Setiati. 2016. Faktor-Faktor yang Berhubungan dengan Sikap Caring yang Dipersiapkan oleh Perawat Pelaksana di Ruang Rawat Inap RSUP Persahabatan Jakarta :Fakultas Kesehatan Universitas Muhammadiyah Yogyakarta. E-Journal Vol 3 No 4.

Tiara.,Lestari. Hubungan Antara Perilaku Caring Perawat Dengan Tingkat Kepuasan Pasien Rawat Inap Di Rumah Sakit Umum Daerah Pringsewu Lampung Tahun 2017.Publish Skripsi, Program Studi Ilmu Keperawatan STIKes Muhammadiyah Pringsewu Lampung Tahun 2017

Watson,J. 2006. Theory of Human Caring. Danish Clinical Nursing Journal. 20 (3): 21-7.

Wijaya.2017. Perilaku Caring dan Kepuasan Pasiendalam Proses Interaksi Pelayanan Keperawatan di RSUD Petala Bumi.STIKes PMC Pekanbaru 